\title{
Chingiz Aitmatov's Creative Works in the National Literature as a Reflection of a New Ethnic Mythology of the Soviet Period
}

\author{
Irina Sovetovna Karabulatova
}

Institute of Social and Political Research, Russian Academy of Sciences, 119991 Moscow, Leninsky Prospect 32a

Flera Sagitovna Sayfulına

Kazan (Volga region) Federal University

Luiza Firdusovna Zamalieva

Kazan (Volga region) Federal University, The Russian Federation, 420021, Kazan, Tatarstan street, 2

Gulsina Mavlutovna Niyazova

Tyumen State University, 345003, The Russian Federation, Tyumen, Semakov street, 10

Doi:10.5901/mjss.2015.v6n6s2p155

Abstract

This article is devoted to the analyzing the literary career of Chingiz Aitmatov in the context of creativity of writers in 1970-1980 years, defining an entire era in the history both national and Russian, World literature, in whose work the wisdom of eastern philosophy is combined with the best traditions of European literature, crossed fundamental aesthetic foundations of cultures of Europe and Asia. The translation of his works into other languages makes the literary heritage of Chingiz Aitmatov the property of all peoples. However, creativity of this writer is of interest from the standpoint of the transformation of ethnic mythology in the context of the new mythology of the Soviet era. The writer outlines "a circle", delimiting themselves from each other in any "identification factor": age, ethnicity, social or gender identity, etc.

Keywords: Kyrgyz literature, creative heritage of Chingiz Aitmatov, literary traditions, literary translations, new mythology

\section{Introduction}

Chingiz Aitmatov is one of the most popular Soviet writers of the 1970s and 1980s, who belonged to well-known national writers, who had won the love and respect of readers during his lifetime. Chingiz Aitmatov was the writer, whose works are revealed in the context of a literary development of the multinational Soviet literature. Kaisyn Guliyev, Rasul Gamzatov, David Kugultinov, Mustai Karim, Amirhan Eniki, Ayaz Gilazov, Chingiz Aitmatov... It was a generation of great humanists, writers, glorifying in their creativity their own national people. Their worksare united with light lyricism and profound wisdom, which captivate and enchant everyone who touches it up to nowadays. Eastern imagery and depth, capacious ideas are inherent creations of each of them. As rightly emphasizes M.S.Miskina, "Aitmatov is allocated a special type of creative thinking, which includes two opposing forms of thought: the east and west". (Miskina, 2004: 5). These personalities of the national literature miraculously came together high literary skill, talent and rare human qualities. They were great romantics, who had kept up their golden autumn youthful enthusiasm, bright sincerity, kindness and humanity. Creativity of Chingiz Aitmatov eloquently illustrates that mental storage mechanisms functionally of equivalent languages in the mind of the writer as a natural bilingua, providing the process of speech activity, determine the total or partial mixing linguocultural codes, "which is expressed in the plan of expression and plan of content interlingual lexical correlations provided social equivalence of languages" (Karabulatova, 2013: 792). Their creativity instilled in readers hope for the best, the belief that kindness, good citizenship, honesty can and should be companions of man for all times. Each of them was a national treasure of the nation, the property of human culture in huge multi-national country. They have become an epoch in the history of both national and Russia, the world literature. Aphoristic thinking of these talents as a reflection of the wisdom of the East philosophy could combine in their work with the best traditions of European literature. The fundamental bases of aesthetic cultures of Europe and Asia are crossed there. It is not 
surprising that their books have been translated into dozens and dozens of languages. Wise words, expressed in their works, caused a huge public outcry.

\section{Materials and Methods}

Last decade, at scientific meetings the issue of creating Common Turkic language, or about worthy translations of the Turkic-speaking authors in other related languages are often raised. In the $2^{\mathrm{d}}$ Congress of the Turkic-speaking peoples of literary magazines (2008) in the speech the General Director of TURKSOY D.Kaseinov sounded the painful and up to the last decade of culture of Turkic-speaking countries the issue of the relationship of Turkish literature, which has been lost in the post-soviet space. For example, the text of the novel "Cassandra's Brand" illustrates, first of all, the multi-vector and poly-aspectuality of communicative dialogue between major languages and cultures poly-communicative and ethnolinguistic cognitive activity within the personality of the writer, that it becomes a determining condition in the characterization of poly-variative Eurasian linguistic personality of new type, where reflected substrate layers of antiquity, the recent historical past and the present.

It should be noted that during the Soviet period, the works of Chingiz Aitmatov had been translated into more than 170 languages, including the Turkic. If we talk about the traditions of the Tatar school of translation, in the Soviet period many famous works of national and Russian authors were translated into the Tatar language active. From the late 1940s until the late 1980s Tatar publishing house, a major publishing center, each year produced about a dozen translated from Russian or national language works. It was about eight to ten percent annually produced in Tatarstan fictions. The most actively translated by Tatar literary works of popular writers at the time are the works of Russian writers as Konstantin Paustovsky, Konstantin Simonov, Sergei Mikhalkov, Yuri Bondarev, Victor Astafev, Vasil Bykov, Valentin Rasputin, Yevgeny Yevtushenko, Kazakh writers Mukhtar Auezov, Sabit Mukanov, Uzbek poet Askad Mukhtar, Georgian writer Nodar Dumbadze and many others. In this regard, it is important to emphasize the works of Chingiz Aitmatov. Almost all the works of this writer was promptly translated into the Tatar language - the native language of his mother (Khamidullin, 2012: 27). Chingiz Aitmatov said at a meeting with Tatarstan President (21 February 2006) that he has a "very deep sense of kinship" with Kazan; He noted that Kazan has a "magical properties", as his maternal ancestors came from these places. He also noted the important role of Tatar intellectuals and members of the Muslim clergy in the formation of national cultures in Central Asia, including Kyrgyz (Khamidullin, 2012: 27).

After decades of stagnation in the development of society and literature in the works of Chingiz Aitmatov, the writer of the time of the "thaw", special attention to the private human fate in the context of the historical destiny of the people, national way of life, feeling the gain of moral and philosophical issues is paid.

The first work, which had brought the worldwide fame to Aitmatov, is a novel "Jamila" (1958). With the translation of Mirgasimov Usmanov (1962) Tatar-speaking readers got to know the works of the great masters of the words of the Kyrgyz people. The tale about a love story that has stood all the tests on a woman's right to personal happiness and social activities, also it had attracted considerable interest among the Tatar readers. Each following translation work of Chingiz Aitmatov is also viewed with deep interest ( Aitmatov, 1962).

In 1961 he published the novel "My Little Poplar in a Red Scarf", which reveals a complex story of love loyalty and friendship, the process of moral downfall of man. As a particularly good translation from the Kyrgyz language we can regard this story of Chingiz Aitmatov in the translation of the Tatar writer Hassan Saryan ("Beaty Asal") (Aitmatov, 1965).We pay special attention to the last novel by Chingiz Aytmatov "Cassandra's Brand" (Aitmatov, 2007). As pointed out by all the researchers of Aitmatov, roots creativity widespread popularity of Aitmatov has its origins in the traditional national culture.

The materials of research have heterogeneous character. Art works of Chingiz Aitmatov were used as sources of. We used a synergetic approach to a central methodology; it is a synthesis of the achievements of the social sciences (Benveniste, 1966; Osipov, 2002) .

We used such basic scientific methods of research, as observation, comparison, compilation, analysis, modeling and forecasting, methods of quantitative and statistical counting. In addition, we applied linguistic methods such as component analysis, the method of cognitive interpretation of the collected linguistic material, methods of experimental psycholinguistics, and the method of synchronous diachronic analysis. In the process of investigation some scientific methods were used: method of linguistic observation and description of certain language facts for obtaining of generalized data, realized with the help of interpretative method, partially component and contextual analysis were used; method of linguostylistic interpretation of fiction text. Using a systematic methodology allowed to analyze large-scale socio-cultural and ethno-linguistic transformation in the perception of the texts of Chingiz Aitmatov. 


\section{Results}

Chingiz Aitmatov successfully wove prairie flowers of Turkic word in luxurious palette of Russian literature. Ethnic identity, on the one hand, reflects the objectively existing features of culture, and on the other - the ability to actively influence the evolution of the ethnic community, increasing interest in national culture and history, contributing to the formation of specific national interests. Today we can only speculate how these cultures are similar and / or were far from each other. Besides creativity the translator was active in the field of linguistics, literary criticism and translation. Not by chance the first translations of Aitmatov were made in the Turkic languages. He participated in the creation of a dictionary of the Tatar language, he had conversations on the radio, dedicated to the problems of preserving the purity of the mother tongue, published numerous articles on his literary skill. the works "My Little Poplar in a Red Scarf" Chingiz Aitmatov was awarded the State Prize of G.Tukaya as a theatrical production, which were showed by the Tatar State Academic Theatre named after Galiaskar Kamal.

Then the following stories of Chingiz Aitmatov as "First Teacher" (1962), "Mother's Field" (1965) also found the Tatar-speaking readers. It is known that up to 1965 Chingiz Aitmatov wrote in the Kyrgyz language. The first story, written in Russian was "Farewell, Gulsary" (the first title was "Death of pacer"). In 1976 the book of Chingiz Aitmatov "The Tales" was published and translated into Tatar by Yahya Khalitov including works of "Farewell, Gulsary", "Mother's Field", "Camel's Eye." (Aitmatov, 1976). For many years the author of translations Yahya Halitov worked in the magazine "Lights of Kazan", as well as in the Tatar book publishing. He is the one of the Tatar writers devoted themselves to translation working full. Since 1952, he has worked on translations of works of Russian writers - Nikolai Tikhonov, Mikhail Sholokhov, Yuri Bondarev, and publishing in Russian translation of the works of the Tatar writer Makhmut Galaw, Latvian writer VilisL atsis and other native and foreign authors. One of the his best translations of his novels are considered as translations of works of Chingiz Aitmatov.

So, a new community - the Soviet people - actively formed in the Soviet period. Chingiz Aitmatov's novel draws "Cassandra's Brand" ixrody is a people without a past, without roots, without family, without any moral and ethical values. "Ixrody phenomenon is surprisingly very promising politically. This is exactly the penetrating power, which, unlike us, without looking back, without fear and without doubt will fight for the victory of communism throughout the world. Family and other family relationships as archaic institutions of the old world of violence will be reset to the dustbin of history is ixrody. Ixrody as carrier's unprecedented personal freedom and spirit will pave the way for a new era of mankind has long foreseen our revolutionary doctrine. Ixrod in the future, not only the liquidator of the old, obsolete, but also created a new world. I have no doubt, great people; geniuses in ixrodial environment will appear more often than usual, archaic. You know - there is complete freedom from family and other ties routine and worries. Children are produced artificially, impersonal and therefore brought up" (Aitmatov, 2007: 229). In his novel Chingiz Aitmatov went further, developing the ideas of Soviet man, the writer reflects on what it may lead (mass reproduction of ixrody, paid surrogacy - incubus, the fall of morals, the extinction of mankind, infertility and the pursuit of death and self-destruction) (Karabulatova, 2014: 263). During the Soviet period the Government for a long time sought to overcome polysubject and unify cultural and ethnolinguistic processes, refusing to account in their policy of regional diversity. And it could not but affect the outlook of citizens. Then Chingiz Aitmatov speculates that intervention in God's Providence leads to strengthening of confrontation on the other, the genetic level, when people become infertile. It was a "silent" protest of the World Soul against artificial man. For example, the space Philotheus monk says in his posthumous letter, which prompted him to engage in the creation of new technologies for artificial insemination: the refusal mother, growing up without tribal roots, emotional emptiness, and rejection of society, in opposition to the society and the rebellion against him, the creation of such people themselves through artificial insemination. ( Aitmatov, 2007). We can see today some parallels between the behavior of cosmic monk Philotheus and actions orthodox fundamentalists and nationalists in different countries of the East and the West (Shavaliev, 2014; Finkelstein, 2002). Now we are seeing the same search themselves and their place in the new conditions of the collapse of the idea of multiculturalism ( Król, 2014; Chaplin, 2011). "This is not the place to pursue those fundamental debates. But since the focus of this essay has been on what governments should do about multiculturalism, it is necessary to ask what follows politically from claims like these" (Chaplin, 2011: 93).

This means that the Ideality continues to shape Materiality. Every crisis in the development of civilization is the "scrapping" of previous socio-economic relations, relations in the system "society-man" and selects a new channel evolution of society. Modern attempts to keep the culture intact lead to inevitable conflict with the development of modern society.

Chingiz Aitmatov anticipates of many contemporary researchers that the ethnic cultures far removed from each other, have a lot of parallels to the archetypal level (Welke et all, 2014). There is no doubt that a similar code land development makes cultures is a similar, though they may be located far from each other in time and space (Welke et all, 
2014). His works pie shows the mythologizing of contemporary consciousness ( Karabulatova 2013; Pritsak 1952; Hübner, 2014).

Thus, we observe the formation of the modern Eurasian language personality of a new type on a constructive basis of linguistic and mental polylogue. In other words, Chingiz Aitmatov expressed concern "about the ethno-demographic and socio-cultural security as an individual, as well as all over the country" and even the entire planet (Zamaletdinov et all, 2014: 164). Russian language leaves the dominant position, freeing up space for new languages-communicants postSoviet reality, transforming into modern intensive communication speakers towards new variation forms.

\section{Discussion}

Identifying themselves in the social space is found and shown in the process of verbal communication. We are witnessing a struggle nomadic Turkic mentality and settled Slavic culture in the minds of Chingiz Aitmatov, This process is reflected in the nature of the construction of his works of art. (Karabulatova \& Polivara, 2013: 833). It should be noted that the penetration of different cultures has always been nurtured and mental and verbal world ethos (Sayfulina et all 2013). The first novel written by Aitmatov, "The day lasts longer than a century" ("Snowstorm stop", 1980) was translated into the Tatar language by Rim Shiriyazdanov, known literary later (Aitmatov, 1990). The translation of the novel "One day - one life" (1990), as well as the original, was a huge public outcry. The word "mankurt" was entered the vocabulary of the Tatar language and has become a common name, a symbol of the irresistible changes that had been occurred in modern man, severing his connection with the eternal foundations of the national way in his life. Chingiz Aitmatov raises the problem of moral choice to scientists because scientists are experimenting and implementing their results in life and scientists are transforming society and the inner life of every member of society (Jensen, 2002). His thoughts echo the reflections of scientists about the extent of responsibility to the world (Kelly, 2006).

It should be noted that shortly before the his death, Chingiz Aitmatov was in Kazan during the shooting the film based on his novel "The day lasts longer than a century." In the two-day stay in the Republic of Tatarstan the meeting to meet with the President of Tatarstan, relatives in the capital area and Kukmorsky district of the Republic were scheduled. In 1988 a well-known novel "Executioner's block" was published, which has also successfully been translated into the Tatar language. The work, where the author allowed himself to speak on the most painful, burning issues of our time, did not leave the reader indifferent. This novel was the author's desperate appeal, addressed to each person. It was performed by the Tatar State Academic Theatre named after Galiaskar Kamal and the audience was forced to shudder again to think not only about the environmental disaster, and more important- the catastrophe of soul. Yes, "Finally, churches and other religious groups can play a vital role in promoting civic virtues. They can, for example, host inter-faith conversations about such issues in which each faith community would be encouraged to present confidently what they take to be the distinctive contributions their tradition can bring to the nurturing of good citizenship, and to listen respectfully to those of others"( Chaplin, 2011: 94).

It is necessary to recognize the fact that the literary heritage of Chingiz Aitmatov has become the property of all the people, the languages of whom they have been translated. His works have not lost the irrelevance, they have great artistic, aesthetic, social and public significance. Bilingual writer Chingiz Aitmatov considered his duty to preserve the national language and national literature, the identity of the peoples and their unique culture. He wrote about the most important - the honor and humanity.

\section{Conclusion}

Expressive words of Rasul Gamzatov the talent Kyrgyz writer is notable: "Chingiz Aitmatov is the talent of the world sound, the wealth of the entire Soviet culture. But he is the Kyrgyz writer, and he expressed the soul of his national people ..." (Shabliovsky, 1971). And it is really, Chingiz Aitmatov is one of those writers who developed and transformed the national tradition for approval by the highest international entity. As more fully and more deeply the writer reflects the lives of the people in its universal and national significance, as the greater the contribution it makes their creativity to the world's artistic heritage. It's time to create a better balance between the mind and emotions (Karabulatova, 2013: 793). Chingiz Aitmatov keenly foresaw the development of the Soviet world towards the revival of the tradition in other postSoviet dimension. Russian culture of the late twentieth - the beginning of the twenty-first century appears field generating narrative strategies of representation "other"/ "foreign", which was the catalyst for pan-European structural and semiotic transformations. "Across the Universe age of man - is the age of the flies. But man is endowed with thought, and it lengthens his life. But it happens and vice versa - drastically reduces." (Aitmatov, 2007: 519). As rightly emphasizes M.Labaschuk, "the interdependence of communication culture, social communication, on the one hand, and the subject 
as autocommunication of microsocium not often get the attention of researchers in the field, especially as there is no coherent theory of the relationship" (Labaschuk, 2004: 6). Today consideration of communication barriers has different meanings, which is already connected not with the problem of overcoming them, and identifies yourself in the culture. Itself complexity of cultural texts defined complication of consciousness as the sender and the recipient, in connection with what we get up in the face of the need for the tolerance of two essential conditions are predetermining when modeling interpretive process as such (Vasilishina et all, 2013). It should be noted that the meaning expressed in the discourse, as a rule, are more accurate than the meanings of specific components of the discourse of discrete units (words, phrases, sentences and so on). However, the complex mechanism of Homo interculturalis actualizes some philosophical an innuendo, which is closely connected with the figure of silence, thus becoming a narrative strategy that defines multiculturalism modern Eurasian linguistic identity. We see the future coming to us today, and not to simply cause a short visit. The future will be with us for a long time.

\section{References}

Aitmatov, Ch. Jamila (translated into Tatar by M. Usmanov), Kazan: Tat.knizh. izdat., 1962, 88 p.

Aitmatov 1965 - Aitmatov Ch. Topolek moy v krasnoy kosynke (translated into Tatar by Kh. Saryan), Kazan: Tat.knizh. izdat., 1965, 120 p.

Aitmatov 1976 - Aitmatov Ch. The Tales (translated into Tatar by Yahya Halitova), Kazan, 1976, 320 p.

Aitmatov 1990 - Aitmatov Ch. I dol'she veka dlitsya den' (translated into Tatar by R.Shiriyazdanov). Kazan: Tat.knizh. izdat., 1990,288 p. Aitmatov 1976 -Aitmatov Chingiz. Pervyy uchitel'. Skazka. Vstupitel'naya stat'ya Yevgeniya Shabliovskiy.Slovo o Chingize Aytmatove. Kiev: Publishing Children's Literature "Veselka", 1976. p.7.

Aitmatov 2007 - Aitmatov Ch. Tavro Kassandry. Moscow: Azbuka-Klassika, 2007, $528 \mathrm{~s}$.

Benveniste 1966 - Émile Benveniste, Problèmes de linguistique générale, vol. I, Paris, 1966.

Chaplin 2011 Jonathan Chaplin, Multiculturalism: a Christian Retrieval, London, Publishing by Theos, 2011, 97 p.

Cribb, Herrmann 2007 - Joe Cribb, Georgina Herrmann (eds), After Alexander: Central Asia before Islam, Oxford, 2007, 530 p.

Jensen 2002 - Rolf Jensen, The Dream Society. How the coming shift from information to imagination will transform your business, St. Petersburg, Publisher: Stockholm School of Economics in St. Petersburg, 2002, p.179.

Finkelstein 2002 - Eitan Finkelstein, Korni Islamskogo Fundamentalizma, in Noviy vek, 1, 2002, Date Views 28.12.2014, http://www.languages-study.com/harah/magazine7.html

Karabulatova 2013 - Irina Sovetovna Karabulatova, The Problems of Linguistic Modeling of New Eurasian Linguistic Personality in Multilinguistic and Mental Environment (by Example of Onomasphere), in Middle-East Journal of Scientific Research, 17 (6), 2013, p. 791-795.

Karabulatova 2014- Irina Sovetovna Karabulatova. Chingiz Aytmatov o sovremennoy yevraziyskoy yazykovoy lichnosti (na materiale romana "Tavro Kassandry"). In: Russkoyazychnyye pisateli v sovremennom mire. Pod nauchn. red. prof. M.Polekhinoy, Vena: Venskiy Literator, 2014, p: 261-265.

Karabulatova, Polivara 2013 - Karabulatova I.S., Polivara Z.V. Turkic and Slavs: bi-polylinguism in globalization and migrations (on an example of Tumen region)Turkic and Slavs: bi-polylinguism in globalization and migrations (on an example of Tumen region), in Middle-East Journal of Scientific Research 17 (6): 832-836, 2013. ISSN 1990-9233. (c) IDOSI Publications, 2013. DOI: 10.5829/idosi.mejsr.2013.17.06.12263

Khamidullin 2012 - Khamidullin L. Tatar literature and translation problems, in Idel, 2012, 11, p.27.

Kelly 2006 - Paul Kelly, Multiculturalism Reconsidered in Paper Presented at the 20th IPSA World Congress 9-13th July 2006, Fukuoka, Japan, Date Views 29.12.2014, http://paperroom.ipsa.org/papers/paper_5457.pdf.

Król 2014 - Marcin Król. Ideas: End of the multiculturalism dream, in Vox Europ, 29.12.2014, Date Views 29.12.2014, http://www.voxeurop.eu/en/content/article/4002671-end-multiculturalism-dream

Labaschuk 2004 - Mihail Labaschuk, Model' kommunikatsii kak semantizatsiya kul'tury, in: Vostok - Rossiya - Zapad: problemy mezhkul'turnoy kommunikatsii: Mezhdunarodnyy sbornik nauchnykh trudov, Pod red. Ye.Ye.Stefanskogo,:izdatel'stvo SaGA, Samara 2004, p. 6-15.

Lyotard 1979 - Jean-François Lyotard, La Condition postmoderne. Rapport sur le savoir, Paris, 1979, 128 p.

Hübner 2014 - Kurt Hübner, Philosophy of Science - Myth - Revelation. The History of a Discovery, Date Views 11.06.2014 http://www.con-spiration.de/texte/english/2007/huebner-e.html.

Osipov 2002 - Gennadiy Vasil'yevich Osipov. Sotsiologiya i sotsial'noye mifotvorchestvo. Moscow: Izdatel'stvo NORMA (Izdatel'skaya gruppa NORMA — INFRA · M), 2002, 656 p.

Pritsak 1952 - Omelian Pritsak. Stammesnamen und Titulaturen der altaischen Volker, in Ural-Altaische Jahrbucher. Bd 24. 1952. H.1-2, p.49-104.

Sayfulina et all 2013 - Sayfulina Flera Sagitovna, Karabulatova lirina Sovetovna, Yusupov Ferits Yusupovich, Gumerov Ilham G. Contemporary issues of textual analysis of Turkic-Tatar literary monuments of Western Siberia, in World Applied Sciences Journal Issue 27 (Education, law, economics, language and communication): 492-496, 2013. ISSN 1818-4952 .C) IDOSI Publications, 2013. DOI: 10.5829/ idosi.mejsr.2013.27.elelc101

Shabliovsky 1971 - Yevgeniy Shabliovsky, Slovo o Chingize Aytmatove, in Literary Gazette, 1971, July 7, Date Views 28.12 .2014 
http://lib.ru/PROZA/AJTMATOW/chingiz.txt

Shavaliev 2014 - Airat Shavaliev, Ukrainian right-wing forces today chanting anti-Russian slogans in the central streets of Kiev and shout hurray Bandera and Shukhevych, Date Views 27.12.2014 http://www.ntv.ru/novosti/242046\#ixzz3NFMUNeO1

Vasilishina et all 2013 - Elena Nikolaevna Vasilichina, Karabulatova Irina Sovetovna, Zamaletdinov Radif Rifkatovich, On the problem of privative opposition in the mental representations of discourse implicature bilingual writer: geopolitonim "Russia" in the works of V. Nabokov, in Bulletin of Oryol State University. Series: New Studies in the Humanities, Oryol, 2013, 5 (34), p. 126-130.

Welke et all 2014 - Tinka Welke, Susanne Raisig, Kati Nowack, Gesa Schaadt, Herbert Hagendorf, Elke van der Meer, Cooking from cold to hot: goal-directedness in simulation and language, in Cognitive Linguistics, Vol.25, Iss.4, 2014, p.559-581.

Zamaletdinov et all 2014 - Zamaletdinov Radif Rifkatovich, Karabulatova Irina Sovetovna, Yarmakeev Iskander Engelevich, Ermakova Elena Nikolaevna, Linguo-Propaedeutics of Ethnic Conflicts as a Basis for Stability in Complex Polyethnic Regions, in Asian Social Science. Vol 10, No.20, 2014, p. 164-173. ISSN 1911-2017; E-ISSN 1911-2025. Published by Canadian Center of Science and Education. Received: June 22, 2014 Accepted: July 15, 2014 Online Published: September 24, 2014, doi:10.5539/ ass.v10n20p1 